\title{
Prevalence of Type 2 Diabetes Mellitus among Hepatitis C Virus-Infected Patients: A Systematic Review and Meta-Analysis
}

\author{
Sintayehu Ambachew ${ }^{a}$ Setegn Eshetie ${ }^{b}$ Demeke Geremew ${ }^{c}$ \\ Aklilu Endalamaw $^{d}$ Mulugeta Melku $^{e}$ \\ ${ }^{a}$ Department of Clinical Chemistry, School of Biomedical and Laboratory Sciences, College of Medicine and \\ Health Sciences, University of Gondar, Gondar, Ethiopia; ${ }^{b}$ Department of Medical Microbiology, School of \\ Biomedical and Laboratory Sciences, College of Medicine and Health Sciences, University of Gondar, \\ Gondar, Ethiopia; 'Department of Immunology and Molecular Biology, School of Biomedical and Laboratory \\ Sciences, College of Medicine and Health Sciences, University of Gondar, Gondar, Ethiopia; ${ }^{\text {Department of }}$ \\ Pediatrics and Child Health Nursing, School of Nursing, College of Medicine and Health Sciences, University of \\ Gondar, Gondar, Ethiopia; 'Department of Hematology and Immunohematology, School of Biomedical and \\ Laboratory Sciences, College of Medicine and Health Sciences, University of Gondar, Gondar, Ethiopia
}

\section{Keywords}

Diabetes mellitus · Hepatitis C virus · Meta-analysis ·

Prevalence

\begin{abstract}
Background: The ever-increasing global prevalence of hepatitis $C$ infection is fueling the burden of diabetes mellitus, which exacerbates various complications and may be a cause of death of millions of people. Several studies have reported that hepatitis $C$ virus infection is an important risk factor for the development of diabetes mellitus. However, fragmented studies have reported variable and inconsistent findings regarding the prevalence of type 2 diabetes mellitus among hepatitis $C$ virus-infected patients. Therefore, this meta-analysis aimed to estimate the overall prevalence of type 2 diabetes mellitus among patients infected with hepatitis C virus. Methods: This systematic review and meta-analysis includes original articles reporting on cohort and crosssectional studies. A systematic search was performed in
\end{abstract}

\begin{tabular}{ll}
\hline KARGER & $\begin{array}{l}\text { (c) } 2018 \text { The Author(s) } \\
\text { Published by S. Karger AG, Basel }\end{array}$ \\
E-Mail karger@karger.com & This article is licensed under the Creative Commons Attribution- \\
www.karger.com/ijd & $\begin{array}{l}\text { NonCommercial-NoDerivatives 4.0 International License (CC BY- } \\
\text { NC-ND) (http://www.karger.com/Services/OpenAccessLicense). } \\
\text { Usage and distribution for commercial purposes as well as any dis- } \\
\text { tribution of modified material requires written permission. }\end{array}$
\end{tabular}

PubMed, ScienceDirect, and Google Scholar. A random-effects meta-analysis model was used to estimate the global pooled prevalence of type 2 diabetes mellitus among hepatitis $C$-infected patients. A sensitivity analysis was conducted to check the stability of the summary estimate. Heterogeneity was assessed using the $R^{2}$ statistic. A subgroup analysis was also conducted based on geographical region. Funnel plots were used to spot publication bias. Results: A total of 40 eligible articles reporting data on 14,765 study participants were included in this meta-analysis. The pooled prevalence of type 2 diabetes mellitus among hepatitis $C$ virusinfected patients was $19.67 \%$ (95\% Cl: 17.25, 22.09). The subgroup analysis showed a pooled prevalence of $27.72 \%(95 \%$ Cl: 20.79, 34.65) in Africa, 20.73\% (95\% Cl: 17.57, 23.90) in Asia, 16.64\% (95\% Cl: 6.79, 26.49) in North America, and $15.02 \%$ (95\% Cl: 10.66, 19.38) in Europe. Conclusions: The

Protocol registration number: PROSPERO International Prospective Register of Systematic Reviews (CRD42018083409).
Sintayehu Ambachew

Department of Clinical Chemistry, School of Biomedical and Laboratory Sciences College of Medicine and Health Sciences, University of Gondar P.O. Box 196, Gondar (Ethiopia)

E-Mail sinte.ambachew@gmail.com 
overall prevalence of type 2 diabetes mellitus among hepatitis $C$ virus-infected patients was considerably higher than in the general population in a global perspective. The highest prevalence was noted in Africa and Asia, followed by North America and Europe. Therefore, early intervention is needed (prevention and early treatment of hepatitis $C$ virus infection) to prevent the development of type 2 diabetes mellitus.

(c) 2018 The Author(s)

Published by S. Karger AG, Basel

\section{Introduction}

Diabetes mellitus (DM) constitutes one of the leading causes of death across the globe, accounting for $8.4 \%$ of global all-cause mortality [1]. DM is known for its complications such as cardiovascular disease, stroke, nephropathy, leg amputation, retinopathy, impaired immunity, and nerve damage [2]. In pregnancy, poorly controlled DM increases the risk of fetal death and other long-term consequences that impact significantly on the quality of life [3].

On the other hand, hepatitis $\mathrm{C}$ virus (HCV) infection is a growing global health threat; approximately 150-200 million people have been infected with it $[4,5]$. Each year, 1.75 million people newly acquire an $\mathrm{HCV}$ infection. The most affected regions are Eastern Mediterranean and European regions, with prevalence rates of 2.3 and $1.5 \%$, respectively [6]. According to some reports, 350,000 people per year die due to HCV-related diseases $[7,8]$.

Though HCV remains a serious public health issue, no vaccination and no post-exposure prophylaxis are available yet [9]. It causes chronic, life-long infections, resulting in progressive liver damage that leads to cirrhosis and hepatocellular carcinoma [5]. HCV also has extrahepatic effects such as cryoglobulinemia, sporadic porphyria cutanea tarda, glomerulonephritis, and thyroid disorders, perhaps due to the impact of the virus on the host immune system [10]. Evidence suggests that slow progression of HCV infection is the major cause of DM; notably, the virus appears to affect glucose metabolism through alteration of the host innate immune response [11]. The prevalence of $\mathrm{DM}$ is on the rise; it is predicted that its prevalence among adults will rise to $10.4 \%$ by 2040 [12].

Not only in high-income countries but also in low- and middle-income countries, the prevalence of DM has risen faster over the past decade [13]. The International Diabetes Federation estimates that 1 in 11 adults has DM, with a global estimate of 425 million. However, DM is unequally distributed across the globe, and some regions are more affected than others depending on the type and number of its various causes [14].

Several studies have reported that HCV infection is associated with type $2 \mathrm{DM}$ (T2DM). Even though the exact biological mechanisms are not fully understood, some hypotheses suggest that a change in carbohydrate and hepatic lipid metabolism, expression of the HCV core protein, and the activity of hepatic tumor necrosis factor- $\alpha$ induce insulin resistance through alterations to the insulin receptor substrate signaling pathway $[15,16]$. Studies reported that the prevalence rates of DM among patients with HCV infection range from 7.4 to $43.2 \%[17,18]$.

However, so far there has been no systematic review and meta-analysis that estimated the global burden of T2DM among HCV-infected patients. We conducted a systematic review and meta-analysis to summarize the existing data on the prevalence of T2DM among HCVinfected patients at the global level. This provides the empirical evidence necessary for researchers, policymakers, and public health stakeholders to derive health-promoting policies, allocate resources, and set priorities for monitoring future trends.

\section{Methods}

\section{Search Strategy}

This systematic review and meta-analysis was conducted according to the Preferred Reporting Items for Systematic Reviews and Meta-Analyses (PRISMA) standard [19]. The study protocol was registered in the PROSPERO International Prospective Register of Systematic Reviews (CRD42018083409). A comprehensive literature search was conducted to identify studies performed on the prevalence of T2DM among HCV-infected patients and published up to December 2017. Searches were carried out systematically in the following electronic bibliographic databases: PubMed, Google Scholar, and ScienceDirect. The following keywords were used to select relevant studies: (Diabetes Mellitus) OR DM [MeSH Terms] AND (Hepatitis) OR (Hepatitis C virus) [MeSH Terms] OR HCV [MeSH Terms] AND prevalence. The search terms were used separately and in combination using Boolean operators like "OR" or "AND." Duplicate data were excluded.

\section{Eligibility Criteria}

Inclusion Criteria

Studies published in peer-reviewed journals and that reported the prevalence of T2DM among HCV-infected patients were included. All studies were original research articles published in English and contained the minimum information (study participants and number of diabetes events) that helps to calculate a pooled estimate of the global prevalence. Moreover, studies were included in which DM was diagnosed (1) using a fasting plasma glucose level $\geq 126 \mathrm{mg} / \mathrm{dL}(7.0 \mathrm{mmol} / \mathrm{L})$, (2) using a 2 -h plasma glucose level $\geq 200 \mathrm{mg} / \mathrm{dL}(11.1 \mathrm{mmol} / \mathrm{L})$ during an oral glucose tolerance test, or (3) using a random plasma glucose level $\geq 200 \mathrm{mg} / \mathrm{dL}$ (11.1
Int J Diabetes Metab 2018;24:29-37 DOI: $10.1159 / 000493945$
Ambachew/Eshetie/Geremew/ Endalamaw/Melku 
Fig. 1. Flow chart depicting the selection of studies for a systematic review and metaanalysis of the prevalence of type 2 diabetes mellitus among patients infected with hepatitis $\mathrm{C}$ virus.
Records identified through
database searching

$(n=1,155)$
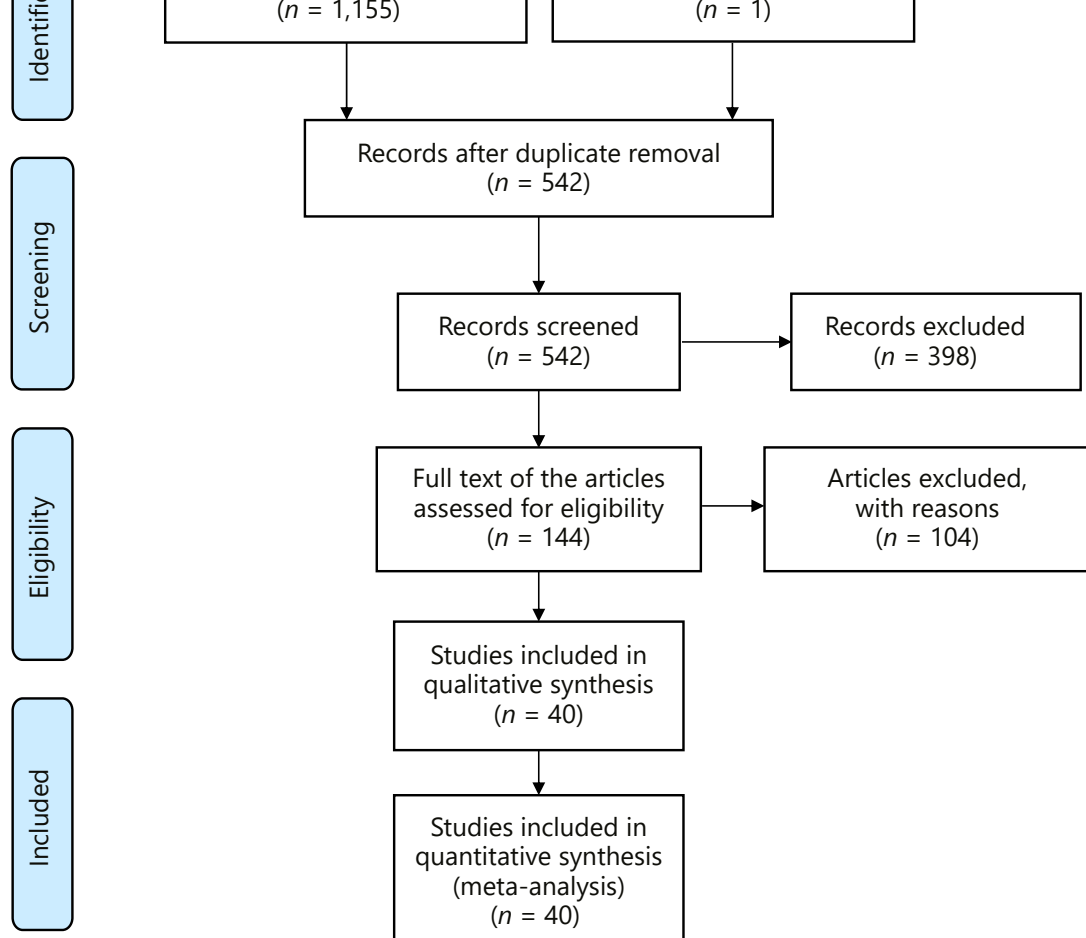

Studies included in

qualitative synthesis $(n=40)$

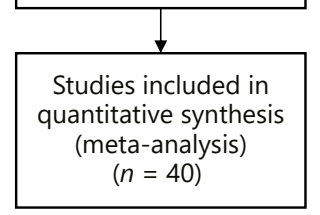

$\mathrm{mmol} / \mathrm{L}$ ) in patients with classic symptoms of hyperglycemia or hyperglycemic crisis. The full texts of the studies meeting these criteria were retrieved and screened to determine their eligibility.

\section{Exclusion Criteria}

Studies on gestational or type $1 \mathrm{DM}$, non-original papers (such as reviews, editorials, letters, and commentaries), and studies in which it was unknown/unclear how DM had been diagnosed were excluded. Studies conducted on patients with HCV-HIV or HCVHBV coinfection or on antiviral drug users were also excluded, as well as those on patients with other causes of liver disease - in particular, those known for the development of DM, such as hemochromatosis. Furthermore, studies on patients who had undergone liver or kidney transplantation were not included in this study.

\section{Study Selection and Quality Assessment}

Three reviewers (S.A., M.M., and A.E.) independently screened the titles and abstracts to consider articles for full-text review. The quality of the studies was assessed using the Joanna Briggs Institute (JBI) quality appraisal criteria [20]. The following items were used to appraise cohort and cross-sectional studies: (1) appropriateness of inclusion criteria; (2) description of study subject and setting; (3) valid and reliable measurement of exposure; (4) objective, standard criteria were used; (5) identification of confounders; (6) strategies for handling confounders; (7) outcome measurement; and
(8) appropriateness of statistical analysis. Studies that reached 50\% and above on the quality scale were considered at low risk of bias. Any disagreement was solved by consensus.

\section{Data Extraction}

A data extraction tool was developed. Information regarding the country, year of publication, type of study, study design, study setting, number of participants, age range of the population, diagnostic criteria for each condition, and number of T2DM cases was retrieved. Data extraction was performed by three reviewers (S.A., M.M., and A.E.) independently, and cross-checked for consistency.

\section{Data Analysis}

The extracted data were entered into Microsoft Excel and analyzed using Stata version 11 (StataCorp, 2009; College Station, TX, USA). A weighted inverse-variance random-effects meta-analysis model was used to obtain an overall summary estimate of the prevalence across studies. A sensitivity analysis was conducted to check the stability of the summary estimate. Assessment of publication bias was performed using funnel plots. Heterogeneity across the studies was evaluated by the $I^{2}$ statistic. $I^{2}$ provides the percentage of variability due to heterogeneity rather than chance differences and/or sampling error, and $I^{2}$ values of 25,50 , and $75 \%$ were considered as representing low, medium, and high heterogeneity, respectively. We performed a subgroup analysis by continent in cases of substantial heterogeneity. 
Table 1. General characteristics and outcomes of the included studies $(n=40)$

\begin{tabular}{|c|c|c|c|c|c|}
\hline Study [Ref.], year & Study design & Country & $\begin{array}{l}\text { Sample } \\
\text { size, } n\end{array}$ & $\begin{array}{l}\text { Prevalence, } \\
\%\end{array}$ & $\begin{array}{l}\text { Study } \\
\text { quality }\end{array}$ \\
\hline Ghouri et al. [21], 2014 & Cross-sectional & Pakistan & 100 & 28 & Good \\
\hline Lecube et al. [68], 2004 & Cross-sectional & Spain & 498 & 23 & Good \\
\hline Akbar et al. [22], 2002 & Cross-sectional & Saudi Arabia & 165 & 21.2 & Good \\
\hline Chiquete et al. [50], 2012 & Cross-sectional & Mexico & 125 & 17.6 & Good \\
\hline Anthony [54], 2016 & Cross-sectional & Rwanda & 298 & 22.48 & Good \\
\hline Caronia et al. [42], 1999 & Cross-sectional & UK & 1,151 & 23.6 & Good \\
\hline Bo et al. [23], 2015 & Cross-sectional & Asia & 1,887 & 9 & Good \\
\hline Azam et al. [24], 2017 & Cross-sectional & Bangladesh & 1,950 & 22.6 & Good \\
\hline Memon et al. [25], 2013 & Cross-sectional & Pakistan & 361 & 31.5 & Good \\
\hline Ryu et al. [26], 2001 & Cross-sectional & South Korea & 95 & 24 & Good \\
\hline Mason et al. [43], 1999 & Cross-sectional & UK & 495 & 21 & Good \\
\hline Rouabhia et al. [55], 2010 & Cross-sectional & Algeria & 261 & 39.1 & Good \\
\hline Selm [27], 2012 & Cross-sectional & Yemen & 71 & 21 & Good \\
\hline Raouf et al. [56], 2012 & Cross-sectional & Egypt & 100 & 24 & Good \\
\hline Hong et al. [28], 2017 & Cohort study & South Korea & 784 & 8.7 & Good \\
\hline Wang et al. [29], 2003 & Cross-sectional & Taiwan & 363 & 18.18 & Good \\
\hline Imazeki et al. [30], 2008 & Cross-sectional & Japan & 544 & 13.6 & Good \\
\hline Antonelli et al. [46], 2005 & Cross-sectional & Italy & 564 & 12.6 & Good \\
\hline Qureshi et al. [31], 2002 & Cross-sectional & Pakistan & 302 & 24.5 & Good \\
\hline Zein et al. [51], 2005 & Cross-sectional & USA & 179 & 14.5 & Good \\
\hline Khan et al. [32], 2013 & Cross-sectional & Pakistan & 164 & 16.46 & Good \\
\hline Arao et al. [33], 2003 & Cross-sectional & Japan & 707 & 20.94 & Good \\
\hline Petit et al. [45], 2001 & Cross-sectional & France & 123 & 13 & Good \\
\hline Chehadeh et al. [34], 2009 & Cross-sectional & Kuwait & 181 & 39.8 & Good \\
\hline Lin et al. [35], 2017 & Cohort study & Taiwan & 930 & 16.7 & Good \\
\hline Huang et al. [36], 2007 & Cross-sectional & Taiwan & 642 & 15 & Good \\
\hline Huang et al. [37], 2008 & Cross-sectional & Taiwan & 683 & 37.8 & Good \\
\hline Kanwal et al. [52], 2015 & Cross-sectional & USA & 528 & 26.9 & Good \\
\hline Antonelli et al. [44], 2004 & Cohort study & Italy & 229 & 14.4 & Good \\
\hline Konishi et al. [38], 2009 & Cohort study & Japan & 197 & 12 & Good \\
\hline Kwon et al. [18], 2005 & Cross-sectional & Korea & 88 & 43.2 & Good \\
\hline Liu et al. [39], 2012 & Cross-sectional & Taiwan & 5,754 & 10.53 & Good \\
\hline Masarone et al. [47], 2007 & Cross-sectional & Italy & 180 & 7.8 & Good \\
\hline Montenegro et al. [48], 2013 & Cohort study & Italy & 616 & 10.1 & Good \\
\hline El-Zayadi et al. [57], 1998 & Cross-sectional & Egypt & 591 & 25.4 & Good \\
\hline İba Yilmaz et al. [49], 2015 & Cross-sectional & Turkey & 62 & 8.1 & Good \\
\hline Cheng et al. [40], 2014 & Cross-sectional & China & 297 & 28.2 & Good \\
\hline Stepanova et al. [53], 2012 & Cohort study & USA & 335 & 7.71 & Good \\
\hline Amarapurkar and Patel [41], 2008 & Cross-sectional & India & 200 & 22 & Good \\
\hline Rao et al. [17], 2015 & Cross-sectional & China & 947 & 7.4 & Good \\
\hline
\end{tabular}

\section{Results}

\section{Characteristics of the Included Studies}

A total of 1,156 potential articles were identified through the systematic literature search. After removal of duplicates, 542 articles were screened by title and abstract, and 144 were found to be eligible for full-text assessment. Of these full-text-screened articles, 40 (including 14,765 study participants) were found to be eligible for meta-analysis. Figure 1 shows the flow chart of study selection and exclusion.

The included studies were conducted all around the world and published up to December 2017. Overall, of the 40 studies included in the meta-analysis that reported the prevalence of T2DM among HCV-infected patients, 23 were from Asia [17, 18, 21-41], 9 were from Europe [4249, 68], 4 were from North America [50-53], and 4 were from Africa [54-57]. Regarding the study design, 34 were
32

Int J Diabetes Metab 2018;24:29-37 DOI: $10.1159 / 000493945$
Ambachew/Eshetie/Geremew/ Endalamaw/Melku 
Table 2. Sensitivity analysis of the included studies to estimate the pooled prevalence of T2DM among HCV-infected patients

\begin{tabular}{|c|c|c|c|}
\hline Study omitted & $\begin{array}{l}\text { Prevalence of T2DM } \\
\text { among HCV-infected } \\
\text { patients, } \%(95 \% \mathrm{CI})\end{array}$ & Study omitted & $\begin{array}{l}\text { Prevalence of T2DM } \\
\text { among HCV-infected } \\
\text { patients, \% (95\% CI) }\end{array}$ \\
\hline Ghouri et al. [21], 2014 & $19.49(17.05,21.93)$ & Khan et al. [32], 2013 & $19.75(17.29,22.21)$ \\
\hline Lecube et al. [68], 2004 & $19.58(17.13,22.02)$ & Arao et al. [33], 2003 & $19.63(17.18,22.09)$ \\
\hline Akbar et al. [22], 2002 & $19.63(17.18,22.08)$ & Petit et al. [45], 2001 & $19.83(17.38,22.29)$ \\
\hline Chiquete et al. [50], 2012 & $19.71(17.26,22.17)$ & Chehadeh et al. [34], 2009 & $19.19(16.80,21.56)$ \\
\hline Anthony et al. [54], 2016 & $19.59(17.15,22.04)$ & Lin et al. [35], 2017 & $19.76(17.27,22.26)$ \\
\hline Caronia et al. [42], 1999 & $19.55(17.12,21.98)$ & Huang et al. [36], 2007 & $19.80(17.32,22.29)$ \\
\hline Bo et al. [23], 2015 & $19.99(17.46,22.51)$ & Huang et al. [37], 2008 & $19.11(16.84,21.39)$ \\
\hline Azam et al. [24], 2017 & $17.15(22.00,19.58)$ & Kanwal et al. [52], 2015 & $19.46(17.0,21.88)$ \\
\hline Memon et al. [25], 2013 & $19.35(16.94,21.75)$ & Antonelli et al. [44], 2004 & $19.81(17.34,22.27)$ \\
\hline Ryu et al. [26], 2001 & $19.58(17.13,22.02)$ & Konishi et al. [38], 2009 & $19.87(17.41,22.33)$ \\
\hline Mason et al. [43], 1999 & $19.63(17.18,22.09)$ & Kwon et al. [18], 2005 & $19.22(16.81,21.63)$ \\
\hline Rouabhia et al. [55], 2010 & $19.17(16.79,21.55)$ & Liu et al. [39], 2012 & $19.98(17.33,22.63)$ \\
\hline Selm [27], 2012 & $19.64(17.20,22.08)$ & Masarone et al. [47], 2007 & $19.98(17.53,22.44)$ \\
\hline Raouf et al. [56], 2012 & $19.57(17.13,22.01)$ & Montenegro et al. [48], 2013 & $19.94(17.46,22.43)$ \\
\hline Hong et al. [28], 2017 & $19.99(17.50,22.47)$ & El-Zayadi et al. [57], 1998 & $19.50(17.08,21.93)$ \\
\hline Wang et al. [29], 2003 & $17.25(22.17,22.17)$ & İba Yilmaz et al. [49], 2015 & $19.94(17.49,22.39)$ \\
\hline Imazeki et al. [30], 2008 & $19.84(17.36,22.33)$ & Cheng et al. [40], 2014 & $19.44(17.02,21.87)$ \\
\hline Antonelli et al. [46], 2005 & $19.87(17.39,22.36)$ & Stepanova et al. [53], 2012 & $19.99(17.54,22.46)$ \\
\hline Qureshi et al. [31], 2002 & $19.54(17.10,21.98)$ & Amarapurkar and Patel [41], 2008 & $19.61(17.16,22.06)$ \\
\hline Zein et al. [51], 2005 & $19.80(17.34,22.26)$ & Rao et al. [17], 2015 & $20.01(17.55,22.49)$ \\
\hline Combined & $19.67(17.25,22.09)$ & & \\
\hline
\end{tabular}

T2DM, type 2 diabetes mellitus; HCV, hepatitis C virus.

cross-sectional and 6 were cohort studies. The JBI quality appraisal checklists indicated that none of the included studies were of poor quality. After quality assessment, the 40 studies were subjected to meta-analysis. Table 1 presents the characteristics and outcomes of the reviewed studies.

\section{Prevalence of T2DM among HCV-Infected Patients}

Forty studies were included in the systematic review and meta-analysis, and all were used for estimation of the prevalence of T2DM among HCV-infected patients. Accordingly, the prevalence of T2DM among HCV-infected patients ranges from $7.4 \%$ [17] to $43.2 \%$ [18]. In this study, the estimated global pooled prevalence of T2DM among HCV-infected patients was 19.67\% (95\% CI: $\left.17.25,22.09 ; I^{2}=96.2 \% ; p=0.000\right)$. The subgroup analysis based on geographical area (continent) showed prevalence rates for T2DM among HCV-infected patients of $27.72 \%$ (95\% CI: 20.79, 34.65) in Africa, $20.73 \%$ (95\% CI: $17.57,23.90)$ in Asia, $16.64 \%$ (95\% CI: 6.79, 26.49) in North America, and 15.02\% (95\% CI: 10.66, 19.38) in Europe (Fig. 2).

\section{Sensitivity Analysis}

We made the sensitivity analysis of the prevalence of T2DM among HCV-infected patients by applying a random-effects model (Table 2). The analysis was done to evaluate the effect of each study on the pooled estimated prevalence of T2DM by excluding each study step by step. The result was that the excluded studies did not show much difference in the prevalence of T2DM among HCVinfected patients.

\section{Publication Bias}

The included studies were visually assessed for potential publication bias with a funnel plot. The funnel plot symmetrically indicates the absence of publication bias, since more than $95 \%$ of the studies fell within the triangular region (Fig. 3).

\section{Discussion}

$\mathrm{HCV}$ infection and DM are two major public health problems worldwide. In this systematic review and metaanalysis, we identified 40 studies at the global level that 


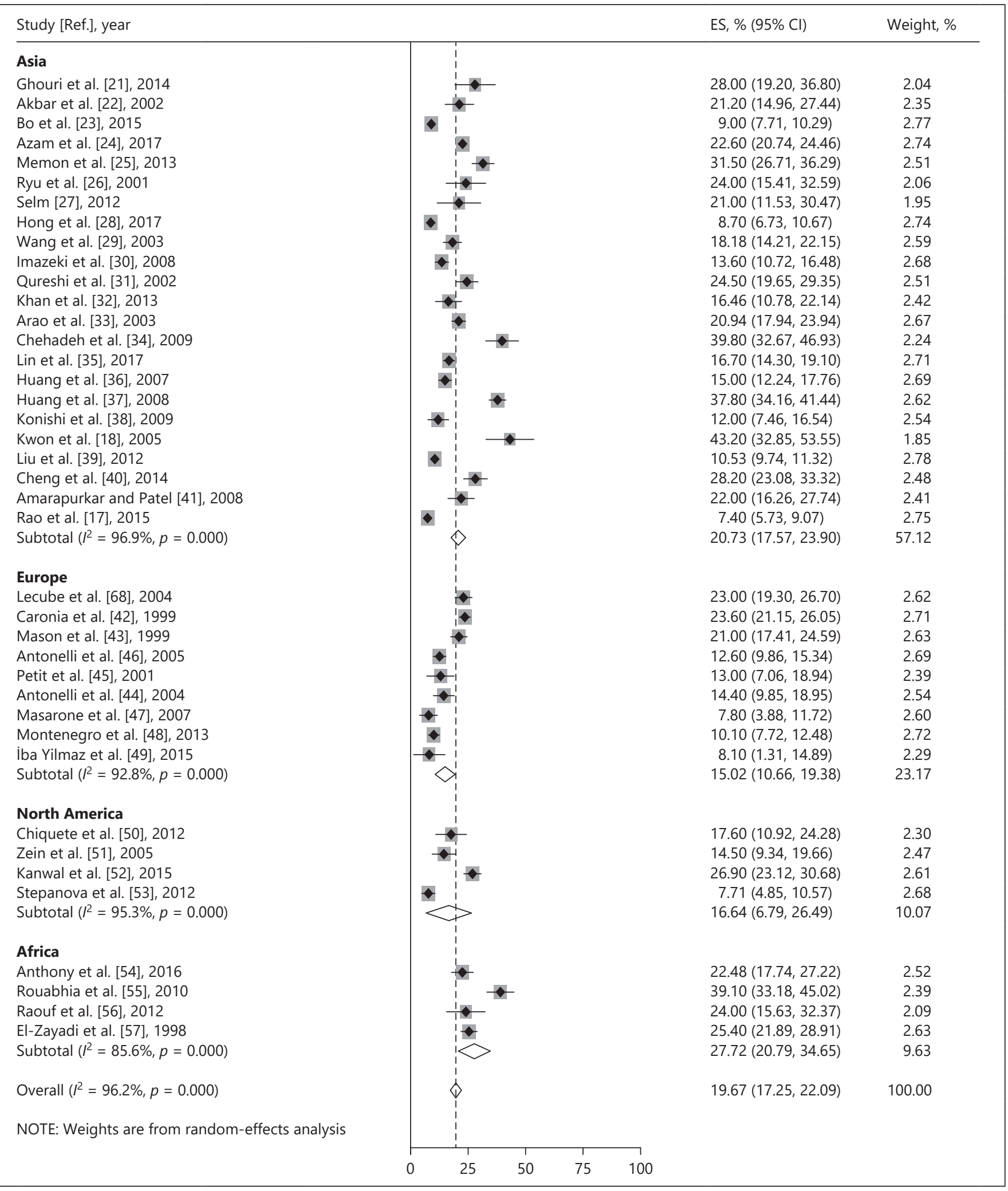

Fig. 2. Forest plot of the global pooled estimates (ES) of the prevalence of type 2 diabetes mellitus among hepatitis $\mathrm{C}$ virus-infected patients from a random-effects model. The midpoint and the length of each segment indicates the prevalence and 95\% CI, whereas the diamond shape shows the combined prevalence of all studies. 


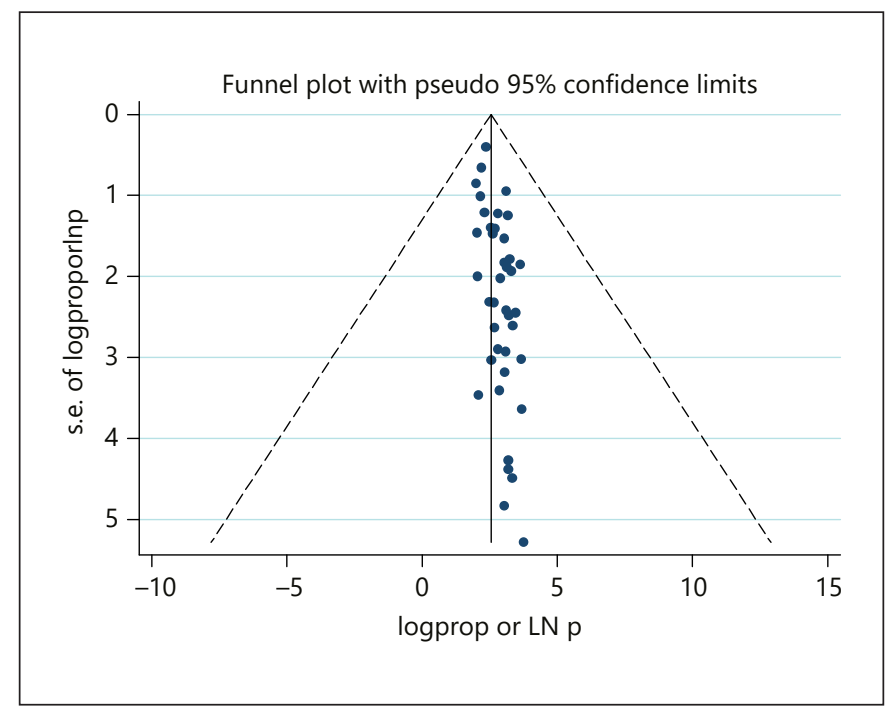

Fig. 3. Funnel plot of the prevalence of type 2 diabetes mellitus among hepatitis $\mathrm{C}$ virus-infected patients.

reported the prevalence of T2DM among HCV-infected patients.

According to those, the pooled prevalence of T2DM among HCV-infected patients was 19.67\% (95\% CI: $17.25,22.09)$. This result was much higher than the global prevalence of DM (8.5\%) among the general population [1]. The reason behind the high prevalence of T2DM among HCV-infected patients in this study could be that patients with $\mathrm{HCV}$ are at risk of developing DM through several pathways. A systematic review and meta-analysis done by Naing et al. [58] showed an excess risk of T2DM in cases with $\mathrm{HCV}$ infection compared to non-HCV-infected controls (OR: 1.63; 95\% CI: 1.11, 2.39). This could be due to the processes by which $\mathrm{HCV}$ causes T2DM, i.e., through direct viral effects, insulin resistance, proinflammatory cytokines, chemokines, and other immune-mediated mechanisms [59]. This was supported by an experimental study that showed that expression of the HCV core protein induces hepatic insulin resistance through alterations of the insulin receptor substrate 1 signaling pathway [60]. Likewise, a study using an animal model has indicated a direct effect of HCV infection on insulin resistance in the liver [61]. In addition to the diabetogenic effects of HCV infection, poor management and treatment of HCV infection, low access to health care, high blood pressure, high cholesterol levels, lack of physical activity, weight gain, and behavioral risk factors might contribute to the increased prevalence of T2DM among $\mathrm{HCV}$-infected patients.

Type 2 Diabetes Mellitus among Hepatitis C Virus-Infected Patients
In the subgroup analysis, the pooled prevalence of T2DM among HCV-infected patients was $27.72 \%$ (95\% CI: $20.79,34.65)$ in Africa, which was higher than the pooled prevalence in Asia (20.73\%; 95\% CI: 17.57, 23.90), in Europe $(15.02 \%$; 95\% CI: 10.66, 19.38), and in North America (16.64\%; 95\% CI: 6.79, 26.49). This variability might be due to differences in ethnicity, sample size, and characteristics of the study population. Differences in access to health care services, the variability in early $\mathrm{HCV}$ screening and diagnosis from country to country, differences in the management of HCV infection, and the lack of an effective strategy for controlling HCV infections in some countries also might contribute to the differences in the above results between continents. Moreover, differences in lifestyle and behavioral factors might also be underlying factors.

Evidence shows that Africa has the highest WHO-estimated regional HCV infection prevalence rate (5.3\%). However, no data were found on the use of medications with HCV infection in Africa, even though treatment, e.g., with peginterferon and ribavirin, is recommended for patients with chronic HCV infection [62]. It is noteworthy that the high prevalence rates of $\mathrm{HCV}$ infection in Africa, accompanied by poor management of $\mathrm{HCV}$ infection, might fuel HCV-related complications, especially T2DM. This is why in the current study the pooled prevalence of T2DM among HCV-infected patients was higher in Africa than on other continents.

According to the current study, the pooled prevalence of T2DM among $\mathrm{HCV}$-infected patients in Africa (27.72\%; 95\% CI: 20.79, 34.65) was much higher than the estimated prevalence of DM in Africa (1\%; rural areas) and in sub-Saharan Africa (5-7\%; urban areas) [63] and than the pooled result of a meta-analysis of DM prevalence $(5.7 \%)$ in Zimbabwe [64]. Likewise, the pooled prevalence of T2DM among HCV-infected patients in Europe (15.02\%; 95\% CI: 10.66, 19.38) was much higher than the estimated prevalence of DM (8.5\%) among the general population in Europe [65]. Furthermore, the pooled prevalence of T2DM among HCV-infected patients in Asia (20.73\%; 95\% CI: 17.57, 23.90) was higher than the estimated prevalence of DM (9\%) among the adult population of the South-East Asia Region [66]. Moreover, the pooled prevalence of T2DM among HCV-infected patients in North America (16.64\%; 95\% CI: 6.79, 26.49) was higher than the estimated prevalence of DM (9.4\%) among the US population [67]. As mentioned before, it is found to be reasonable that $\mathrm{HCV}$ infection might contribute to the rising burden of T2DM.

Int J Diabetes Metab 2018;24:29-37 


\section{Conclusions}

Despite the great heterogeneity and lack of original studies in some countries, our study observed a high prevalence of T2DM among HCV-infected patients compared to the general population. Moreover, the pooled prevalence in Africa was higher than in Europe and North America. Therefore, early intervention is needed (prevention and early treatment of HCV infection) to prevent the development of T2DM. This helps to reduce the coexistence of HCV infection and T2DM as well as exacerbated complications. Besides, policymakers, researchers, and stakeholders should consider effective strategies and preventive measures regarding $\mathrm{HCV}$ infection and T2DM.

\section{Statement of Ethics}

The authors have no ethical conflicts to disclose.

\section{Disclosure Statement}

The authors declare that they have no competing interests. The study received no funding.

\section{Data Availability}

The data will be available upon request from the corresponding author.

\section{Author Contributions}

S.A.: conception of the research protocol, design of the study, review of the literature, data extraction, and statistical analysis. S.A. and A.E.: data analysis and interpretation and drafting of the manuscript. M.M. and S.E.: data interpretation and review of the manuscript. S.A., D.G., and A.E.: data extraction and quality assessment. All authors critically revised the paper and they agree to be accountable for all aspects of the work.

\section{References}

1 World Health Organization. Global report on diabetes. Geneva: World Health Organization; 2016.

2 Papatheodorou K, Papanas N, Banach M, Papazoglou D, Edmonds M. Complications of diabetes 2016. J Diabetes Res. 2016;2016: 6989453.

3 Buchanan TA, Xiang AH, Page KA. Gestational diabetes mellitus: risks and management during and after pregnancy. Nat Rev Endocrinol. 2012 Nov;8(11):639-49.

4 Mohd Hanafiah K, Groeger J, Flaxman AD, Wiersma ST. Global epidemiology of hepatitis $C$ virus infection: new estimates of age-specific antibody to HCV seroprevalence. Hepatology. 2013 Apr;57(4):1333-42.

5 Thrift AP, El-Serag HB, Kanwal F. Global epidemiology and burden of HCV infection and HCV-related disease. Nat Rev Gastroenterol Hepatol. 2017 Feb;14(2):122-32.

6 World Health Organization. Global hepatitis report 2017. Geneva: World Health Organization; 2017.

7 Cacoub P, Poynard T, Ghillani P, Charlotte F, Olivi M, Piette JC, et al. Extrahepatic manifestations of chronic hepatitis C. MULTIVIRC Group. Multidepartment Virus C. Arthritis Rheum. 1999 Oct;42(10):2204-12.

8 Perz JF, Armstrong GL, Farrington LA, Hutin YJ, Bell BP. The contributions of hepatitis B virus and hepatitis $C$ virus infections to cirrhosis and primary liver cancer worldwide. J Hepatol. 2006 Oct; 45(4):529-38.

9 Shepard CW, Finelli L, Alter MJ. Global epidemiology of hepatitis $\mathrm{C}$ virus infection. Lancet Infect Dis. 2005 Sep;5(9):558-67.

10 Cacoub P, Gragnani L, Comarmond C, Zignego AL. Extrahepatic manifestations of chronic hepatitis C virus infection. Dig Liver Dis. 2014 Dec;46 Suppl 5:S165-73.

11 Negro F, Alaei M. Hepatitis C virus and type 2 diabetes. World J Gastroenterol. 2009 Apr; 15(13):1537-47.

12 Ogurtsova K, da Rocha Fernandes JD, Huang Y, Linnenkamp U, Guariguata L, Cho NH, et al. IDF Diabetes Atlas: global estimates for the prevalence of diabetes for 2015 and 2040. Diabetes Res Clin Pract. 2017 Jun;128:40-50.

13 Whiting DR, Guariguata L, Weil C, Shaw J. IDF Diabetes Atlas: global estimates of the prevalence of diabetes for 2011 and 2030. Diabetes Res Clin Pract. 2011 Dec;94(3):311-21.

14 Cho NH. Q\&A: Five questions on the 2015 IDF Diabetes Atlas. Diabetes Res Clin Pract. 2016 May;115:157-9.

15 Moriya K, Yotsuyanagi H, Shintani Y, Fujie H, Ishibashi $\mathrm{K}$, Matsuura $\mathrm{Y}$, et al. Hepatitis $\mathrm{C}$ virus core protein induces hepatic steatosis in transgenic mice. J Gen Virol. 1997 Jul;78(Pt 7):152731.

16 Everhart J. A confluence of epidemics: does hepatitis $\mathrm{C}$ cause type 2 diabetes? Hepatology. 2001 Mar;33(3):762-3.

17 Rao H, Wei L, Li H, Yang R, Zhang H, Shang J, et al.; CCgenos Study Group. Prevalence of abnormal glycometabolism in treatment-naive patients with hepatitis $\mathrm{C}$ virus infection in a Chinese Han population. J Gastroenterol Hepatol. 2015 Jun;30(6):1049-56.

18 Kwon SY, Kim SS, Kwon OS, Kwon KA, Chung MG, Park DK, et al. Prognostic significance of glycaemic control in patients with $\mathrm{HBV}$ and HCV-related cirrhosis and diabetes mellitus. Diabet Med. 2005 Nov;22(11):1530-5.

19 Moher D, Liberati A, Tetzlaff J, Altman DG PRISMA Group. Preferred reporting items for systematic reviews and meta-analyses: the PRISMA statement. PLoS Med. 2009 Jul; 6(7):e1000097.

20 Munn Z, Moola S, Riitano D, Lisy K. The development of a critical appraisal tool for use in systematic reviews addressing questions of prevalence. Int J Health Policy Manag. 2014 Aug; 3(3):123-8.

21 Ghouri A, Kumar S, Khan SA, Ghani MH, Aslam S, Asadullah. Frequency of Type 2 Diabetes Mellitus in Patients with Chronic Hepatitis C Virus Infection. JLUMHS. 2014;13(2): 51-6.

22 Akbar DH, Siddique AM, Ahmed MM. Prevalence of type-2 diabetes in patients with hepatitis $C$ and $B$ virus infection in Jeddah, Saudi Arabia. Med Princ Pract. 2002 Apr-Jun;11(2):82-5.

23 Bo Q, Orsenigo R, Wang J, Griffel L, Brass C. Glucose abnormalities in Asian patients with chronic hepatitis C. Drug Des Devel Ther. 2015 Nov;9:6009-17.

24 Azam G, Alam S, Khan AS, Giasuddin RS, Khan M. High Prevalence of Diabetes Mellitus among Adult Patients with Viral Hepatitis C than Hepatitis B. Int J Life Sci Scienti Res. 2017; 3(5):1365-9.

25 Memon MS, Arain ZI, Naz F, Zaki M, Kumar S, Burney AA. Prevalence of type 2 diabetes mellitus in hepatitis $C$ virus infected population: a Southeast Asian study. J Diabetes Res. 2013;2013:539361.

26 Ryu JK, Lee SB, Hong SJ, Lee S. Association of chronic hepatitis $\mathrm{C}$ virus infection and diabetes mellitus in Korean patients. Korean J Intern Med. 2001 Mar;16(1):18-23.

27 Selm SB. Prevalence of Type 2 Diabetes Mellitus among Patients with Hepatitis C Virus Infection in Aden. J Diabetes Metab. 2012;3(8):152. 
28 Hong YS, Chang Y, Ryu S, Cainzos-Achirica M, Kwon MJ, Zhang Y, et al. Hepatitis B and C virus infection and diabetes mellitus: A cohort study. Sci Rep. 2017 Jul;7(1):4606.

29 Wang CS, Wang ST, Yao WJ, Chang TT, Chou P. Community-based study of hepatitis $\mathrm{C}$ virus infection and type 2 diabetes: an association affected by age and hepatitis severity status. Am J Epidemiol. 2003 Dec;158(12):1154-60.

30 Imazeki F, Yokosuka O, Fukai K, Kanda T, Kojima H, Saisho H. Prevalence of diabetes mellitus and insulin resistance in patients with chronic hepatitis C: comparison with hepatitis $B$ virus-infected and hepatitis $C$ virus-cleared patients. Liver Int. 2008 Mar;28(3):355-62.

31 Qureshi H, Ahsan T, Mujeeb SA, Jawad F, Mehdi I, Ahmed W, et al. Diabetes mellitus is equally frequent in chronic HCV and HBV infection. J Pak Med Assoc. 2002 Jul;52(7):280-3.

32 Khan IA, Bukhari MH, Khokhar MS. Comparison of Association of Diabetes Mellitus in Hepatitis C Virus Infection and Hepatitis B Virus Infection. Ann King Edward Med U. 2013; 19(1):37.

33 Arao M, Murase K, Kusakabe A, Yoshioka K, Fukuzawa Y, Ishikawa T, et al. Prevalence of diabetes mellitus in Japanese patients infected chronically with hepatitis C virus. J Gastroenterol. 2003;38(4):355-60.

34 Chehadeh W, Abdella N, Ben-Nakhi A, AlArouj M, Al-Nakib W. Risk factors for the development of diabetes mellitus in chronic hepatitis $\mathrm{C}$ virus genotype 4 infection. J Gastroenterol Hepatol. 2009 Jan;24(1):42-8.

35 Lin YJ, Shaw TG, Yang HI, Lu SN, Jen CL, Wang LY, et al.; R.E.V.E.A.L.-HCV Study Group. Chronic hepatitis $\mathrm{C}$ virus infection and the risk for diabetes: a community-based prospective study. Liver Int. 2017 Feb;37(2):17986.

36 Huang JF, Dai CY, Hwang SJ, Ho CK, Hsiao PJ, Hsieh MY, et al. Hepatitis C viremia increases the association with type 2 diabetes mellitus in a hepatitis $B$ and $C$ endemic area: an epidemiological link with virological implication. Am J Gastroenterol. 2007 Jun;102(6):1237-43.

37 Huang JF, Yu ML, Dai CY, Hsieh MY, Hwang SJ, Hsiao PJ, et al. Reappraisal of the characteristics of glucose abnormalities in patients with chronic hepatitis C infection. Am J Gastroenterol. 2008 Aug;103(8):1933-40.

38 Konishi I, Hiasa Y, Shigematsu S, Hirooka M, Furukawa S, Abe M, et al. Diabetes pattern on the $75 \mathrm{~g}$ oral glucose tolerance test is a risk factor for hepatocellular carcinoma in patients with hepatitis C virus. Liver Int. 2009 Sep;29(8): 1194-201.

39 Liu JL, Chen JY, Chen CT, Wang JH, Lin CY, Chen PF, et al. Community-based cross-sectional study: the association of lipids with hepatitis C seropositivity and diabetes mellitus. J Gastroenterol Hepatol. 2012 Nov;27(11):168894.

40 Cheng Z, Zhou B, Shi X, Zhang Y, Zhang L, Chen L, et al. Extrahepatic manifestations of chronic hepatitis $\mathrm{C}$ virus infection: 297 cases from a tertiary medical center in Beijing, China. Chin Med J (Engl). 2014;127(7):1206-10.
41 Amarapurkar DN, Patel ND. Increased prevalence of type II diabetes mellitus in hepatitis C virus infection in western India. Trop Gastroenterol. 2008 Jul-Sep;29(3):148-52.

42 Caronia S, Taylor K, Pagliaro L, Carr C, Palazzo U, Petrik J, et al. Further evidence for an association between non-insulin-dependent diabetes mellitus and chronic hepatitis $\mathrm{C}$ virus infection. Hepatology. 1999 Oct;30(4):1059-63.

43 Mason AL, Lau JY, Hoang N, Qian K, Alexander GJ, Xu L, et al. Association of diabetes mellitus and chronic hepatitis $\mathrm{C}$ virus infection. Hepatology. 1999 Feb;29(2):328-33.

44 Antonelli A, Ferri C, Fallahi P, Sebastiani M, Nesti C, Barani L, et al. Type 2 diabetes in hepatitis C-related mixed cryoglobulinaemia patients. Rheumatology (Oxford). 2004 Feb; 43(2):238-40.

45 Petit JM, Bour JB, Galland-Jos C, Minello A, Verges B, Guiguet M, et al. Risk factors for diabetes mellitus and early insulin resistance in chronic hepatitis C. J Hepatol. 2001 Aug;35(2): 279-83.

46 Antonelli A, Ferri C, Fallahi P, Pampana A, Ferrari SM, Goglia F, et al. Hepatitis C virus infection: evidence for an association with type 2 diabetes. Diabetes Care. 2005 Oct;28(10):254850.

47 Masarone M, La Mura V, Bruno S, Gaeta GB, Vecchione R, Carrino F, et al. Steatohepatitis is associated with diabetes and fibrosis in genotype $1 \mathrm{~b} \mathrm{HCV}$-related chronic liver disease. J Viral Hepat. 2007 Oct;14(10):714-20.

48 Montenegro L, De Michina A, Misciagna G, Guerra V, Di Leo A. Virus C hepatitis and type 2 diabetes: a cohort study in southern Italy. Am J Gastroenterol. 2013 Jul;108(7):1108-11.

49 İba Yilmaz S, Erol S, Özbeks A, Parlak M. Distribution of viral genotypes and extrahepatic manifestations in patients with chronic hepatitis C in Eastern Turkey. Turk J Med Sci. 2015; 45(1):70-5.

50 Chiquete E, Ochoa-Guzmán A, García-Lamas L, Anaya-Gómez F, Gutiérrez-Manjarrez JI, Sánchez-Orozco LV, et al. Hepatitis C virus infection and type 2 diabetes mellitus in Mexican patients. Rev Med Inst Mex Seguro Soc. 2012 Sep-Oct;50(5):481-6.

51 Zein CO, Levy C, Basu A, Zein NN. Chronic hepatitis $\mathrm{C}$ and type II diabetes mellitus: a prospective cross-sectional study. Am J Gastroenterol. 2005 Jan;100(1):48-55.

52 Kanwal F, White DL, Jiao L, Tavakoli-Tabasi S, Sansgiry S, Ramsey DJ, et al. Genetic variants in interleukin-28B are associated with diabetes and diabetes-related complications in patients with chronic hepatitis $C$ virus infection. Dig Dis Sci. 2015 Jul;60(7):2030-7.

53 Stepanova M, Lam B, Younossi Y, Srishord MK, Younossi ZM. Association of hepatitis C with insulin resistance and type 2 diabetes in US general population: the impact of the epidemic of obesity. J Viral Hepat. 2012 May;19(5):341-5.

54 Anthony B. Prevalence of type 2 diabetes mellitus in adult patients with hepatitis $C$ virus infection and associated laboratory markers. Experience at Rwanda Military Hospital: A cross sectional descriptive study [Master's thesis]. University of Rwanda; 2016.
55 Rouabhia S, Malek R, Bounecer H, Dekaken A, Bendali Amor F, Sadelaoud M, et al. Prevalence of type 2 diabetes in Algerian patients with hepatitis $\mathrm{C}$ virus infection. World J Gastroenterol. 2010 Jul;16(27):3427-31.

56 Raouf MA, Yousry ZA, Hindy OM, Eissa SS, Soliman DS. Study of diabetes mellitus among patients with hepatitis C virus. Egypt J Intern Med. 2012;24(1):17.

57 El-Zayadi AR, Selim OE, Hamdy H, Dabbous $\mathrm{H}$, Ahdy A, Moniem S. Association of chronic hepatitis $C$ infection and diabetes mellitus. Trop Gastroenterol. 1998 Oct-Dec;19(4):1414.

58 Naing C, Mak JW, Ahmed SI, Maung M. Relationship between hepatitis $\mathrm{C}$ virus infection and type 2 diabetes mellitus: meta-analysis. World J Gastroenterol. 2012 Apr;18(14):164251.

59 Antonelli A, Ferrari SM, Giuggioli D, Di Domenicantonio A, Ruffilli I, Corrado A, et al. Hepatitis $C$ virus infection and type 1 and type 2 diabetes mellitus. World J Diabetes. 2014 Oct; 5(5):586-600.

60 Banerjee S, Saito K, Ait-Goughoulte M, Meyer K, Ray RB, Ray R. Hepatitis C virus core protein upregulates serine phosphorylation of insulin receptor substrate-1 and impairs the downstream akt/protein kinase B signaling pathway for insulin resistance. J Virol. 2008 Mar;82(6): 2606-12.

61 Shintani Y, Fujie H, Miyoshi H, Tsutsumi T, Tsukamoto K, Kimura S, et al. Hepatitis C virus infection and diabetes: direct involvement of the virus in the development of insulin resistance. Gastroenterology. 2004 Mar; 126(3): 840-8.

62 Karoney MJ, Siika AM. Hepatitis C virus (HCV) infection in Africa: a review. Pan Afr Med J. 2013;14(1):44.

63 Kengne AP, Amoah AG, Mbanya JC. Cardiovascular complications of diabetes mellitus in sub-Saharan Africa. Circulation. 2005 Dec; 112(23):3592-601.

64 Mutowo M, Gowda U, Mangwiro JC, Lorgelly P, Owen A, Renzaho A. Prevalence of diabetes in Zimbabwe: a systematic review with metaanalysis. Int J Public Health. 2015 Jan;60(1): 1-11.

65 Tamayo T, Rosenbauer J, Wild SH, Spijkerman AM, Baan C, Forouhi NG, et al. Diabetes in Europe: an update. Diabetes Res Clin Pract. 2014 Feb;103(2):206-17.

66 Roglic G, Varghese C, Thamarangsi T. Diabetes in South-East Asia: burden, gaps, challenges and ways forward. 2016.

67 Centers for Disease Control and Prevention. National Diabetes Statistics Report, 2014: Estimates of Diabetes and Its Burden in the United States. Atlanta: US Department of Health and Human Services; 2014.

68 Lecube A, Hernández C, Genescà J, Esteban JI, Jardí R, Simó R. High prevalence of glucose abnormalities in patients with hepatitis $\mathrm{C}$ virus infection: a multivariate analysis considering the liver injury. Diabetes Care. 2004 May;27(5): 1171-5. 